\title{
Women's Contributions to the Progress of Mathematics: Lights and Shadows
}

\author{
Elisabetta Strickland
}

It's undoubtedly worthwhile to analyse the role played by women in mathematics. Men have obtained many recognitions in this field, but the same cannot be said about women. Indeed, how many people are aware of the contributions of Hypatia, Émilie du Châtelet, Maria Gaetana Agnesi, Sophie Germaine, Mary Fairfax Somerville, Sonya Kovalevsky and Emmy Noether? Nevertheless, today we can confirm that these women made substantial contributions to the progress of mathematics. For this reason they deserve our attention, but also because they had extraordinary lives and peculiar personalities which are interesting to observe closely.

It has been proven that when human beings started to develop the concept of number, women approached this concept in the same way as men $[1, \mathrm{p} .11]$. As a matter of fact, anthropologists are convinced that primitive women had a relatively high order of creative intelligence, absolutely as lively as that of primitive men.

Cuneiform documents on clay tablets from the region of ancient Mesopotamia have shown that around 4700 B.C. there were already expert mathematicians at work and when the Code of Hammurabi was in force among the Babylonians, women took care of business and accounting, exactly as in ancient Egypt. Nevertheless, none of the women experts in mathematics in these ancient cultures are known by name: we have to wait for the Hellenic age to discover the names of women who were expert in mathematics.

The school of Pythagoras, which started around 539 B.C. in the Greek colony of Croton in southern Italy, was also attended by women, and some of the teachers were women too. Pythagoras married one of them, Theano, and two of their daughters ran the school after the death of Pythagoras.

The first notable woman mathematician was the Egyptian Hypatia, born around 370 A.D. in Alexandria [2]. She was the daughter of the mathematician Theon, who was the librarian of the Library of Alexandria and educated her as if she were a boy. In about 400 A.D., she became headmistress of the Platonist school at Alexandria, where she imparted the knowledge passed down from Plato and Aristotle. Hypatia was a popular lecturer, drawing students from all parts of the empire. She was a Hellenistic pagan. Her contributions to science are many: she is credited with the 
invention of an astrolabe [1, p. 28], wrote commentaries on Diophantine equations and on the conics of Apollonius, edited her father's commentary on Euclid's Elements, wrote a text called The Astronomical Canon, contributed to the invention of the hydrometer and the hydroscope, and worked on the charting of celestial bodies. When Bishop Cyril and his Christian followers accused her of causing religious turmoil, Hypatia was assassinated in a ferocious way: a Christian mob of monks waylaid Hypatia's chariot as she travelled through the town. The monks stripped her naked, dragged her through the streets to a church, where they killed her, flaying her body with sharp oyster shells and burned the parts. This cruel death didn't prevent Hypatia from securing her place in history.

After the fall of Constantinople, there was a decline in intellectual progress; even after the Renaissance the status of women changed very slowly. One has to wait until the seventeenth century to hear again of a prominent woman mathematician.

In France during the Age of Reason it was not easy for women to have an education which was not too superficial. The only institution which performed this duty was founded during the reign of Louis XIV, the Sun King: the Institut of Saint-Cyr, where young ladies were prepared to become the wives of aristocrats.

This was the general situation of education in France when in 1706 Émilie de Breteuil was born in Paris, daughter of Louis Nicholas le Tonnier, baron of Breteuil, head of the protocol at Court [1, p. 52]. She had very good teachers at home and they were all astonished by her capability in understanding mathematics. Often they didn't even understand properly what she was saying, as her ideas were much more sophisticated than those they were accustomed to. When she was nineteen years old, she married the Marquis of Châtelet, who was colonel of a regiment. Émilie du Châtelet was left often alone and spent her time studying and enjoying society. She was so smart in mathematics that all the best minds in Paris became her friends. She fell in love with one of them, Voltaire, and went to live with him in the country house of the Châtelet family, at Cirey-sur-Blaise. There du Chatelet was introduced to the work of Leibniz and Newton, which occupied her mind for fifteen years. She became so deep in her thoughts, that she inspired Voltaire to write the novel Candide. The couple could live their love story freely because du Chatelet's husband admired Voltaire and decided to tolerate their menage a trois. Du Chatelet liked her routine: she could work every morning on her papers and in the evenings she could devote herself to the pleasures of the fashionable world, which suited her personality as much as science books. During those years, she published with Voltaire the Istitutions de physique, which was devoted to the work of Leibniz, and translated Newton's Principia from Latin, establishing her reputation for competence among contemporaries.

When she was expecting her fourth child, she admitted that she didn't know who the father was, maybe even not Voltaire, as at the time she was having an affair with the poet Saint Lambert. She really didn't care about the issue and preferred to spend those months studying Newton's theories. Voltaire himself wrote that when the baby was born, the little girl was put on a volume of geometry and the mother went to bed taking the papers she was writing along with her. Apparently du Chatelet seemed well, she spent her convalescence together with her husband, Voltaire and Saint 
Lambert taking care of her. But all of a sudden, late one afternoon, she died quietly. Voltaire was beside himself, and declared that he had lost not only his lover, but half of himself.

While these peculiar events where taking place in France, in Italy women were becoming interested in the study of mathematics. The most notable among them was Maria Gaetana Agnesi, born in Milan on May 16, 1718.

Agnesi was a child prodigy; she learned seven languages before her thirteenth birthday, and her father, Pietro Agnesi, who held a chair at the University of Bologna, and mother, Anna Brivio, gave her the best possible education, with special emphasis on mathematics and philosophy, so that she learned from the work of masters such as Newton, Leibniz, Fermat, Descartes and Euler. Her father organized seminars at home and distinguished intellectuals gathered to listen Agnesi's lectures; but she was shy by nature, and asked her father for permission to enter a convent in order to spend her life studying in peace. This was not granted, not least because Agnesi had twenty-one siblings and half-siblings and when he lost his last wife, Agnesi was asked to help with their education. Her first book, which she started writing at the age of twenty, entitled Instituzioni analitiche ad uso della gioventù italiana (Analytical Institutions for the use of Italian Youths), was a treatise on differential and integral calculus. She spent ten years on it and when it was published in 1748, the academic world was extremely impressed by her work. But her reputation reached extraordinary heights when she discussed a planar cubic curve, originally studied by Fermat, which she called a versiera, from the Latin word vertere, as the curve actually turned. But this word was interpreted as an abbreviation of the word avversiera, or 'wife of the devil', so it happened that John Colson, professor of mathematics at Cambridge, translated the word versiera as "witch', and the curve discussed by Agnesi became known as the witch of Agnesi.

Because of her results in mathematics, Agnesi became a member of the Accademia delle Scienze of Bologna and was given a diamond ring by the Empress Maria Theresa, to whom she had dedicated her book. Even Pope Benedict XIV showed appreciation for her work and secured a teaching position for her at the University of Bologna after her father's death. But Agnesi preferred to devote herself to help the poor, and she was appointed head of the female section of the Hospice Trivulzio in Milan. She died at age 81: the city of Milan named a street after her, and a crater on Venus is named in her honour.

Like Émilie du Châtelet, another notable mathematician, physicist and philosopher of the eighteenth century was also French: Sophie Germaine, born in Paris on April 1, 1776.

Germaine was 13 when the Bastille fell, and as the turmoil in Paris made it impossible for her to spend time outside the house, she turned to her father's library. In the book of Jean-Étienne Montucla, Histoire des Mathèmatiques, she read the story of the death of Archimedes, killed by a Roman soldier during the sack of Syracuse in 212 B.C. while he was totally absorbed by a problem in geometry. Germaine decided that if mathematics had held such fascination for Archimedes, it was a subject worthy of study. The family didn't approve of her attraction to mathematics and, when night came, they would deny her warm clothes and proper lighting in her 
bedroom. She waited until they went to sleep, took out candles, wrapped herself in blankets and worked until dawn. One morning Germaine was found asleep on her desk, the ink frozen in the ink horn; this made them realise that she had to be free to do mathematics [1, p. 85].

In 1794, when she was 18, the École Polytechnique opened, but as a woman Germaine was not permitted to attend. She managed to obtain the lecture notes of Lagrange, who was a faculty member, and started to send him her work using the pseudonym of M. Le Blanc. Lagrange recognised the quality of her work and was determined to meet M. Le Blanc, so Germaine was forced to disclose her true identity. Lagrange didn't mind that Germaine was a woman, and helped her in her work.

Initially Germaine had a deep interest in number theory and, again under the pseudonym of M. Le Blanc, she wrote to Carl Friedrich Gauss, presenting some of her work on Fermat's Last Theorem. Gauss thought well of Germaine, even after he discovered that she was a woman, but he generally did not review her work, so finally the correspondence ended without the two having ever met.

In 1811 Germaine participated in a competition sponsored by the Académie des sciences in Paris concerning the experiments of the physicist Ernst Chladni with vibrating metal plates. The object of the competition was to give a mathematical theory for the vibration of an elastic surface. She didn't succeed this first time, because the jury said the equations were not established, but she tried again and at the third attempt, in 1816, she won the prize and this allowed her to have a reputation on a par with that of Cauchy, Ampere, Navier, Poisson and Fourier.

But Germaine's best work was in number theory, as she made a significant contribution to Fermat's Last Theorem. She wrote again to Gauss to ask his opinion on her proof for a special case, but Gauss never answered. As we know, Andrew Wiles solved the problem in 1994, but Germaine's work two hundred years before is considered substantial.

Finally Gauss did his best to convince the University of Göttingen to confer a doctor's degree honoris causa on Germaine, but she never had the chance to receive it, since she died of breast cancer in 1831. When the state official who had to fill her death certificate came to her house, he refused to write 'mathematician' for her profession, writing property owner instead. When the Eiffel Tower was erected and it was decided to inscribe in it the names of the seventy-two scientists whose work on elasticity contributed to the enterprise, Germaine's name was left out, perhaps because she was a woman. But today Germaine is considered one of the founders of mathematical physics.

We now leave France and turn to the British contribution of women in mathematics. This leads us to some interesting reflections on the life of Mary Fairfax Somerville, whose extraordinary mathematical talent came to the surface by a lucky accident. She was born in Scotland, at Jedburgh, in 1780. When she was a little girl, she didn't like studying; as a matter of fact at the age of ten she was barely capable of reading. One day, when she was a teenager, she was leafing through a fashion magazine and noticed some algebraic symbols, which she found fascinating [3, p. 46]. She was at that time attending Nasmyth's Academy, in order to learn painting 
and dancing and there she overheard the master of the school talking about Euclid's Elements of Geometry and succeeded in obtaining a copy of the book through her youngest brother's tutor, together with a text of algebra [3, p. 49]. She started to spend her time studying at night at candlelight, behaviour which her family found deeply worrying. It was decided that she would marry her cousin Samuel Greig. This is exactly what happened, and in the first three years of marriage she had two sons, one of whom died shortly after birth. Her husband was against her wish to study mathematics, but he died in 1807, leaving her financially independent for the first time in her life. By this time she had pretty well mastered geometry and astronomy.

At the age of 33, she won a prize solving a problem on Diophantine equations which had been posed by a popular science journal. The editor gave her a list of classics in mathematics suited to form a solid background in the field. Her family still found her manner of life abnormal and convinced her to marry a second time with another cousin, William Somerville. This time she was lucky, as her new husband was an intelligent and handsome surgeon, who moved with Fairfax Somerville to London, where she had the chance to study and meet all the most outstanding intellectuals of that time, such as the mathematician Pierre Laplace and the explorers Georges Cuvier and Sir Edward Perry.

In 1826 Fairfax Somerville submitted an article to the Royal Society on the magnetic properties of ultraviolet rays in the solar spectrum and in 1838 she was appointed honorary member of the Royal Astronomical Society, together with Caroline Lucretia Herschel. Her second husband also had health problems and Fairfax Somerville had to move first to Paris, then to Italy. This didn't prevent her from writing two volumes on behalf of the Society of Useful Knowledge, Mechanism of the Heavens about the work of Laplace and one about Newton's Principia, which had to be translated from Latin into English for the British academic institutions. Notwithstanding her role as mother of five children (she had four from the second marriage), in 1843 her book The Connection of the Physical Sciences was published and was followed in 1848 by another one called Physical Geography. At the age of 89, after the death of her second husband, she wrote Molecular and Microscopic Science, a treatise on the form and the rotation of the earth and the tides of the ocean and atmosphere, plus other texts on various topics. She also wrote also her memoirs, Personal Recollections [3]. She died at 92, in Naples. Most of the popularity of her writings is due to her clear style and her enthusiasm for the subjects. No one has any doubt about her being one of the most outstanding British women scientists.

Up to know, we have talked about women mathematicians in France, Italy and Great Britain. What can be said about other countries?

An interesting answer can be found in Russia. Sofia (or Sophie) Vasilyevna Kovalevskaya was born in Moscow in 1850. Her father, Vasily Vasilyevich KorvinKrukovsky, served in the Imperial Russian Army. She was the first major Russian female mathematician as well as a public advocate of feminism and a noted writer whose works include both fiction and nonfiction.

There are some transliterations of her name; she herself changed it in Sonya Kovalevsky in her last academic publications. Her mother Yelizaveta decided to nurture her interest in mathematics by hiring a well known tutor for her higher education, 
Alexander Nikolayevich Strannoliubsky, who taught her calculus [4, p. 7]. Because her father prevented her from completing her education in Russia, she decided to contract a fictitious marriage with Vladimir Kovalevsky, a young palaeontology student and together they emigrated from Russia. Kovalevskaya began attending the University of Heidelberg, in Germany, studying under such teachers as the physicists Helmholtz and Kirkhoff and the chemist Bunsen [5, p. 424]. But when she learned that the mathematician Karl Weierstrass was teaching in Berlin, she asked him to give her private lessons: the University would not allow her to audit classes. In 1874 she presented three papers to the University of Göttingen as her doctoral dissertation: the first was on partial differential equations, containing the well known Cauchy-Kovalevsky theorem, the second one on the dynamics of Saturn's rings and the third one on elliptic integrals. Weierstrass supported her and she obtained her doctorate in mathematics, summa cum laude, without having to pass oral exams or defend her thesis, thus becoming the first woman in Europe to hold that degree. After this achievement, she returned to Russia and gave birth to a daughter, Fufa. After a year devoted to raising her baby, she resumed her work in mathematics: in order to do this, she left her husband, who suffered from mood swings, and entrusted Fufa to her sister, Anyuta. Vladimir couldn't stand this and, also beleaguered by a stock swindle, committed suicide.

Kovalevskaya was distraught over this tragedy, and asked the Swedish mathematician Gösta Mittag-Leffler, whom she had known as a fellow student of Weierstrass, to help her. She thus obtained a position as a docent at Stockholm University. In 1884 she was appointed a professor (without a chair) and became the editor of Acta Mathematica. In 1888 she won the Prix Bordin of the French Académie des sciences for the celebrated discovery of what is known as the 'Kovalevsky top', on the complete integrability of a rigid body motion about a fixed point: the only other tops were those of Euler and Lagrange. Finally in 1889 she was appointed Professor with a chair, the first woman to hold such a position in northern Europe. She also became a member of the Russian Academy of Sciences, but was never offered a professorship in Russia. She died of complications from a flu in 1891 at the age of forty-one, after a trip of pleasure. She was buried in Sweden, at Solna. The Soviet Union honoured her with a postage stamp showing her portrait. Kovalevskaya also wrote a memoir, A Russian Childhood [4], plays (in collaboration with Anne Charlotte Edgren-Leffler, the sister of Gösta Mittag-Leffler), and a partly autobiographical novel, Nihilist Girl.

At this point it's a duty to talk about Emmy Noether, another extraordinary mathematician, the founder of modern algebra. She was born in a Jewish family in Germany, at Erlangen, in 1882. Her father, Max Noether, professor of mathematics at the University of Erlangen, was at that time already a celebrity, thanks to his theory of algebraic functions. Noether had a wonderful character, she was full of joy and loved having fun, so she grew up dividing her time between social activities and her father's lectures, which were attended also by her brother Fritz. She obtained her degree in mathematics in 1907, defending a thesis 'On complete systems of invariants for ternary biquadratic forms' under the supervision of Paul Gordan. She herself defined her work 'a jungle of formulas'. After her father's death, David Hilbert con- 
vinced Noether to go to Göttingen, where he believed she could be useful, with her knowledge of invariants, for his joint work with Felix Klein on the general theory of relativity. Hilbert tried desperately to convince the university to give her a position, but he didn't succeed, because she was a woman. He was so exasperated by the refusal, that one day at a faculty meeting he burst out with his famous words 'This is a university, not a bathhouse!'. But Hilbert had such an high opinion of the young lady, that he ignored the faculty's decision and started to send her to give lectures in his place. Only at the end of the first world war was Noether officially allowed to teach at the university. In the 1920s she developed the theory of ideals in commutative rings. She loved working at the beautiful Institute of Mathematics of Göttingen, which had been constructed with the financial help of the Rockefeller Foundation.

In 1932 she was the first woman to give a talk at the International Congress of Mathematicians, in Zurich. But under the Nazis, because she was Jewish, she was compelled to leave for the United States, where she was offered a job at Bryn Mawr College in Pennsylvania, very close to the Institute for Advanced Study of Princeton. During her American years, she worked on noncommutative rings and hypercomplex algebras and united the theory of group representations with the theory of modules and ideals. But she didn't enjoy the privileges she had received in the States for long, as she died at 53 as the consequence of an apparently successful operation. Albert Einstein wrote in the New York Times [May 4, 1935, p. 12] that 'Fraulein Noether was the most significant creative mathematical genius thus far produced since the higher education of women began'.

Hilbert [1, p. 152] said that in Göttingen people usually referred to-Noether as 'der Noether', i.e., using the masculine article, because of a respectful recognition of her power as a creative thinker who appeared to have broken through the barrier of sex.

One last glimpse at Italy: as the $150^{\text {th }}$ anniversary of its founding as a modern state is being celebrated at the moment of this writing, it's quite natural to wonder if women have made important contributions to mathematics during this period.

Let me mention two relevant names in this context: Maria Pastori (1895-1975) and Maria Cibrario Cinquini (1905-1992). Pastori had as master and colleague the great mathematical physicist Bruno Finzi. She didn't come from a wealthy family or grow up in an intellectual environment, but nevertheless she succeeded in entering the Scuola Normale Superiore di Pisa, where she defended her degree thesis in 1920. In 1939 she obtained a chair at the University of Messina and in 1947 she returned to her hometown Milan, holding the chair of rational mechanics. During her career she published about one hundred papers, obtaining important results in tensor analysis and relativity. She wrote a book in collaboration with Bruno Finzi, entitled Calcolo Tensoriale ed Applicazioni (Tensor Calculus and its Applications), still considered today a milestone in mathematical literature.

Maria Cibrario Cinquini obtained her degree in 1927 at the University of Turin, under the supervision of Guido Fubini. As an assistant professor she worked with Giuseppe Peano and in one of her first eight papers written during the six years after her graduation, she analyzed 24 statements derived from the definition of limit, following Peano's work. After his death, she worked with Francesco Giacomo Tricomi 
and Guido Fubini, and won the Corrado Segre Prize for young assistant professors three years in a row (1926-1928). She became internationally renowned for her discovery that hyperbolic-elliptic differential equations could give a description of transonic aerodynamic phenomena. She married her colleague Silvio Cinquini, and they had three children. Her family duties didn't prevent her from solving the Goursat problem for nonlinear hyperbolic equations and the Cauchy problem for systems of first order differential equations.

Some final words about women in mathematics today. Many women are firstclass mathematicians: as a matter of fact, women have never before enjoyed such prominence in mathematics. At the most recent International Congress of Mathematics, many of the 178 speakers were women, including Parimala, an Indian mathematician, Claire Voisin, French, winner of the Clay Research Award in 2008, and an Italian, Matilde Marcolli, who works at Caltech in California.

Moreover, in 2010 for the first time a woman was elected President of the International Mathematical Union: she is the Belgian Ingrid Daubechies, first woman full professor of mathematics at the University of Princeton, expert in the theory of wavelets. And again in 2010 a woman was elected President of the European Mathematical Society: Marta Sanz-Solè, Spanish, from the University of Barcelona, an expert in stochastic processes.

No woman has yet been the recipient of the Fields Medal, the most important prize awarded for mathematics, but we have good reason to hope that in 2014, when the next International Congress of Mathematicians takes place in Seoul, Korea, the prize will finally be awarded to a woman.

\section{References}

1. L.M. Osen, Women in Mathematics. Cambridge, MA, MIT Press, 1974.

2. M. Dzielska, Hypatia of Alexandria. Cambridge, MA, Harvard University Press, 1996.

3. M. Somerville, Personal Recollections. From Early Life to Old Age. London, John Murray, 1874. Available at: http://www.gutenberg.org/ebooks/27747. Last accessed 19 June 2011.

4. S. Kovalevskaya, A Russian Childhood. Heidelberg, Springer, 1978.

5. E. Temple Bell, Men of Mathematics (1937). New York, Touchstone, 1986. 